\title{
THE SHIFT TOWARDS SMART CITIES IN SOUTHEAST ASIAN CITIES
}

\author{
The Role of Urban Governance
}

\author{
Author 1 Thibault PILSUDSKI, SEC-FCL; Singapore \\ Author 2 Si Ying TAN, NUS-LKYSPP; Singapore \\ Author 3 Devisari TUNAS, SEC-FCL; Singapore \\ Author 4 Fabien CLAVIER, SEC-FCL; Singapore \\ Author 5 Andrew STOKOLS, SEC-FCL; Singapore \\ Author 6 Araz TAEIHAGH, NUS-LKYSPP; Singapore
}

\section{Abstract}

Smart cities utilise technological and digital solutions to resolve urban issues, to enhance accessibility of services, and increase the quality of life (ASEAN, 2018). In 2018, Singapore leveraged its ASEAN presidency to initiate the ASEAN Smart Cities Network to develop a collaborative forum to improve translation of smart technologies between ASEAN cities by exploring potential synergies and complementarities, developing tailored action plans and sharing best practices. However, the translation, adoption and implementation of technologies across unique geographical, developmental and governance contexts vary substantially (Taeihagh, 2017). Without sufficiently understanding these variations, the translation process will likely fail. To understand these variations and their implications for city governance, we seek to unpack the different institutional forces that shape the adoption and implementation of such technologies. The paper aims therefore to identify key aspects of urban governance that guide the adoption and implementation of smart city technologies, by questioning (1) the drivers for smart city adoption, (2) the origin of policy ideas, (3) the factors hindering or facilitating their local translation, and (4) the impact of smart city development on city-level governance. This paper is part of an ongoing research on smart cities in Indonesia.

\section{Keywords}

Smart City, Southeast Asia, Policy Capacity, Policy Mobility, Policy Entrepreneur

\section{Introduction}

Much literature on smart cities development typically considers it as a technical or managerial issue (Meijer \& Bolívar, 2016), focusing on the potential of specific technologies to improve management or planning in cities, but rarely examining the role of governance and the social and political constructions that hinder or facilitate the adoption of new technologies in city government or planning processes. Taeihagh and Lim (2018) claim that the term 'smart city' has emerged as a new concept amidst the acceleration of competition among cities for businesses and talent, which has driven cities to place more emphasis on 
the development of engineering solutions and economic feasibility for achieving desired urban development goals. Nevertheless, the conceptualisation of smart city development needs to go beyond technological solutionism, and be acknowledged as a complex social system that entails many wicked problems and competing interests (Kitchin 2016). Furthermore, Kitchin (2015) also emphasises the lack of empirical studies and contextualised comparative cases on smart cities. There is also a need to understand what the reality of deploying smart systems means for the vast majority of emerging cities in the global south, especially Asia.

This paper compares the development of smart city in two Indonesian cities; Bandung and Jakarta, which have both been at the forefront of smart city development in Indonesia since 2013-2014. It is a first step towards the creation of a framework that can be used to systematically analyse the interplay between urban governance and smart cities development in ASEAN. This will be achieved by drawing theoretical literature from public policy which include the Multiple Streams Framework (MSF) (Kingdon, 1984), instrument constituencies (Voß \& Simons, 2014), policy mobility (McCann, 2011), policy capacity (Wu et al., 2015), or policy ideas (Cox \& Béland 2013), to investigate the roles of political leadership, institutions, policy capacities, and policy ideas in the adoption and development of smart cities.

This paper draws upon several fieldworks in Bandung and Jakarta in 2018-2019, including semi-structured interviews conducted with key actors in the municipality departments as well as external actors involved in Bandung and Jakarta smart cities; from university, private sector and non-governmental organisations. This information was supplemented by analysis of government reports, official presentations during conferences, twitter accounts, and national newspapers (in English and Indonesian).

The fielworks were preceded by a literature review of some relevant policy concepts to analyse smart city adoption and translation, and contributed to the elaboration of the following questions that will structure this paper: (1) What are the drivers for smart city adoption and how are policies for smart city development formulated? (2) Where do the policy ideas and inspirations come from? (3) How is it translated locally and what are the factors facilitating/hindering policy adoption? (4) How does the smart city development agenda affect as well as inform city-level governance? Our findings are aimed at helping both government and non-government actors such as technology producers, city authorities, and multilateral funders to develop practice insights and policy recommendations to achieve the goals for smart city development.

\section{Literature Review}

The following section intends to introduce the literature on MSF, policy entrepreneur, policy mobility, instrument constituency, and policy capacity as analytical frameworks for our case studies. The MSF was developed by Kingdon (1984) to understand why some ideas are captured by policy-makers and make it to the agenda setting, while others do not. The MSF does not think that human beings are rational actors, hence policy-makers are incapable of making the best policy decisions by picking the best solutions uniquely crafted for a policy issue (Cairney, 2018). Instead, Kingdon postulates that policy problems, policy solutions, and politics, each constitute an independent process, or stream, and at the same time, they 
could also form intermingling forces that influence one another in the policy process. Eventually, at a specific point in time, a policy window opens allowing the coupling of the three streams. This coupling can be realised by a policy entrepreneur, who "invest his resources, time, energy, reputation, money to promote a position in return for anticipated future gain" (Kingdon, 2011). When a window opens, policy entrepreneurs will push their policy proposals ("pet projects"), attempting to couple it with the two other streams. While the focus of Kingdon's studies was on the domestic political context of the USA, the MSF literature has since then evolved, with Bache \& Reardon (2013), for instance, emphasising the importance of international networks for the development of ideas in the policy stream. Lovell (2016), who studied smart metering policy in Australia, also found that MSF would be better supplemented with theoretical insights from policy mobility as ideas move easily across national boundaries.

In the examination of smart city development, it is also important to examine how policy ideas are transported from one jurisdiction to another when cities learn from one another in their respective quest to be 'smarter'. In this respect, it is relevant to investigate how the concepts of policy mobility and policy transfer play a part to facilitate this process. Policy mobility differentiates itself from policy transfer by questioning the state-centredness of traditional policy transfer literature and its "implicit literalism" that suggests the importation of fully formed policies (Peck \& Theodore, 2001). It also focuses much more on interurban "transfers" of ideas. In this context of international policy mobility where policy ideas travel between cities, policy entrepreneurs are assumed to be "searching globally for best practices to embrace, "cutting-edge" cities to emulate, and "hot" experts from whom to learn (Peck \& Theodore, 2008). They tap into and utilise extralocal connections - ranging from official intergovernmental alliances to individual relationships with colleagues elsewhere - to learn about policy models and physically bring experts to the city to inform locals about cuttingedge policies."

In another addition to the MSF, Voss and Simons (2014) developed further on the network of actors behind transnational policy stream with the concept of instrument constituencies. It is defined as a transnational network of heterogeneous actors that "stay united because of their common "fidelity" not to a political agenda or defined problem but rather to their advocacy of a particular instrument(s) as a superior technique of public governance" (Béland \& Howlett, 2016). In the context of smart city development in Indonesia, we apply this concept to focus largely on domestic actors who possess international experiences and are open to transboundary and cross-jurisdictional policy learning, as well as staying committed to a common goal of elevating the city's development through the deployment of various policy instruments.

Finally, we complement these concepts with policy capacity to explain the ability of city governments to receive and implement new ideas. Proposed by $\mathrm{Wu}$ et al. (2015), policy capacity is defined as a function of three sets of skills and competencies (political, operational, and analytical) at three levels of resources and capabilities (systemic, organisational and individual). In Wu et al.'s conceptualisation, political capacity is associated with having the political acumen to steer the overarching governmental functions towards goal attainment by asserting one's authority and by building public's trust towards the government. Operational capacity, on the other hand, pertains to the ability of government to roll-out policy effectively. Analytical capacity boils down to the bolts and nuts 
of policy-making. In particular, it relates to the ability to apply technical knowledge to design and implement policies in the most efficient and cost-effective manner.

\section{Comparative Analysis of the Role of Urban Governance in Smart Cities Translation in Bandung and Jakarta}

Jakarta and Bandung have been widely recognised nationally and internationally as the pioneers of Smart City in Indonesia. Jakarta, the capital of Indonesia, with a population of over 10 million (2017) (BPS, 2018), and Bandung, the capital of West Java Province, with a population close to 3 million (2017) (BPS Kota Bandung, 2018), and their urban surroundings form one of the largest urban agglomerations in Southeast Asia. Faced with challenges of rapid urbanisation, population growth and increasing urban complexities, authorities in both cities have been actively exploring various technical and policy solutions to help them address the issues.

Due to the decentralisation policy that has been implemented beginning after Suharto's departure in 1999, the role of central government in directing local planning and development has been increasingly superseded by local mayors. Decentralisation has also led to divergence between certain successful "superstar" cities and regions and cities with less capacity, in Indonesia (Firman, 2014, Von Leubke, 2009) as is the case in other countries. The recent development directions in Indonesian cities and regencies, including in Jakarta and Bandung, could be attributed to the presence of strong and charismatic leadership at the local level. For example, the development of smart cities in Indonesia are largely driven by the local leadership, such as Basuki Tjahaja Purnama, the former Governor of Jakarta and Ridwan Kamil, the former Mayor of Bandung, who has since been elected as the Governor of West Java. Purnama previously had a short stint of political career as the Regent of Belitung regency (2005-2007) before pairing up with Joko Widodo in Jakarta's gubernatorial campaign. He was elected as Vice Governor, and subsequently replaced Widodo as Governor when the later was elected as President. Kamil meanwhile, came from non civil-servant background; he was a planning practitioner and academic prior to his political career.

\subsection{The Drivers behind the Smart City Adoption}

In both Jakarta and Bandung, the role of policy entrepreneurs has been instrumental, and this is represented by their strong local leadership that spurs the adoption of smart city development. We use the MSF to unpack the roles and influences that policy entrepreneurs, Kamil in Bandung and Purnama in Jakarta, have exerted in smart city adoption, and their framings of the problem.

Bandung

In Bandung, even though the smart city is mentioned briefly in some presentations during the preceding Dada Rosada mayorship, it was Kamil who launched the concept as one of his campaign promises in 2013 when he was running to become the mayor of Bandung (Ispranoto, 2013 September 14). Kamil decided to enter the municipal campaign quite late, only eight months before the election. Though without political experience, Kamil had been active in the policy circle since 2008 through the Bandung Creative City Forum (BCCF), a nonprofit organisation, which he created with a network of like-minded individuals to promote 
the concept of creative city. He worked as the first president of the forum, which gave him sufficient visibility that paved the way for his entry into politics (Mada, 2015 November 6). The mayor election opened a window of opportunity in the political stream, but also in the problem stream since the former mayor was being tried for corruption and ultimately charged with a 10-years prison sentence. Coming from the BCCF, Kamil could have framed existing city problems to couple it with his creative city solutions. But vehicular ideas like the creative city "serve to make things happen at a particular time, after which their time may be up" (McLennan, 2004). Having been advocated since the last five years, keeping the creative city concept on top of the city agenda could have led to the risk of the idea becoming quickly outdated. By framing the smart city as a solution for greater transparency, efficiency and accountability, the smart city narrative also allowed Kamil to capitalise on a contemporary policy idea that has taken root in many other countries as a means to strengthen city-level governance.

Jakarta

In Jakarta, smart city development has been credited to Purnama. He began working on the Jakarta's smart city programme during his vice governor position under Governor Widodo. Both set a new impulse in the city's management, aiming at improving public service and transparency (Wardhani, 2014), by setting up a transparent communication system to make it more accessible for the citizens to file for complaints against lapses in public services. When Widodo became president in 2012, and left Purnama with the position of governor, it opened a window of opportunity for Purnama to push the concept of smart city to be a central agenda in Jakarta to promote transparency and a greater efficiency. As the scale of complaints was too difficult to be managed by short message service (SMS), upgrading to a system that would better handle these complaints appeared to be a natural development for the government to be more responsive to the citizens' feedback. Cox \& Béland suggest that skilled policy entrepreneur have "an intuitive sense for which ideas fit a newly opened policy window" (2014). In line with that, we argue that it is also a major quality of a policy entrepreneur to be sensitive enough to determine the gaps in addressing the needs of citizens, and when a policy idea that fill this gap would likely take off. In the case of Bandung and Jakarta, Kamil and Purnama have been able to sense that smart city's time has come for Indonesia, and this acumen has propelled Bandung and Jakarta to be the first-movers of smart city adoption at the national level.

\subsection{Inspirations for the Smart City Visions}

The smart city is an urban concept, similar to the creative city or the sustainable city. Policy mobility studies consider these concepts or ideas to be in continuous transformation and mutation (Peck, 2011) along their journey. In a policy mobility context, policy entrepreneurs, depending on their background and network, can play a key role as agent of translation for policy ideas.

\section{Bandung}

In the case of Bandung, Kamil appeared to have been the main translator of the smart city concept. Building on his overseas experiences through his studies at UC Berkeley and his urban design projects abroad as an architect (in Singapore, Thailand, Bahrain, China, Vietnam, United Arab Emirates), Kamil was able to draw on his own experiences to push for 
the development of a smart city in Bandung. Among various illuminating examples, Singapore stands out as a model, with Kamil mentioning in a 2017 interview with Govinsider that "Bandung is designed to be as competitive as Singapore, as modern as Singapore," but will retain its "strong traditions as Bali. A combination of Bali and Singapore - that will be my Bandung vision" (Chambers, 2017 April 11). This particular mention for Singapore nevertheless never materialised in a close cooperation for the development of Bandung Smart City. A more tangible source of inspiration for Bandung was Rio de Janeiro's Operations Centre developed by IBM in 2010 (Paschoal \& Wegrich, 2017), as this directly influenced Kamil's decision to initiate the Bandung Command Center. While IBM was involved through a "rush engagement" rather than a solid partnership (Labtek Indie, personal communication, April 2nd, 2019), there was never any form of cooperation between Rio and Bandung. Kamil was in this case the main agent of translation; tapping into a globally referenced case and adapting it to the local situation.

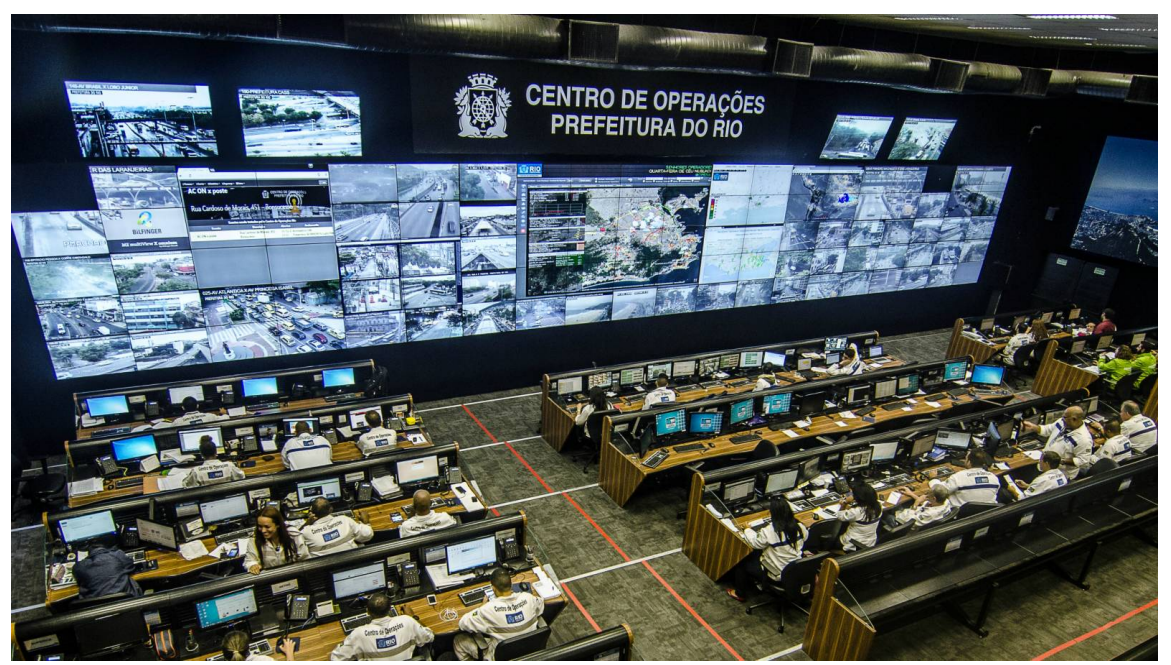

Figure 1: Launched in $\mathbf{2 0 1 0}$ with the help of IBM, the Rio Operation Centre became a typical case study for Smart City. Retrieved from: http://icities4greengrowth.in/casestudy/rio-dejaneiros-operations-centre-rio-de-janeiro-brazil

\section{Jakarta}

In Jakarta, Purnama did not benefit from an international career to provide him a wide range of urban experiences. He had apparently adopted a more 'agnostic' vision of the smart city, and appeared to be receptive towards new ideas as long as they make sense. However, when discussed inspiration models for Jakarta, Singapore, as for Bandung, once again appeared at the forefront and became a model that Jakarta was seriously contemplating to emulate. As Purnama said in an interview; "Let's be honest, if we want to take the example of another city, we can imitate Singapore. We cannot imitate European cities; it's different. Europe has existed for hundreds of years. Their development was conducted in the 1800s" (Wardhani et al., 2015 November 19th). But he also looked at other developed Asian cities like Tokyo and Seoul (Chambers \& Basu, 2016). If like in Bandung, the prominence of the Singapore model did not exert a strong influence in the smart city adoption process in Jakarta, it does shed some light on what McCann calls "city upon hills" (McCann, 2013; Cohen, 2015), which refers to a small cluster of cities of which stories are always presented, policies compared, or situation benchmarked. In the context of the new ASEAN Smart City 
Network, it will be interesting to see if Bandung or Jakarta would eventually achieve such statuses and manage to become prominent examples for other followers in the smart city movement.

\subsection{The Local Translation of the Smart City}

While no transnational instrument constituency appeared to be strongly influencing the creation of the smart city in Bandung and Jakarta, both cities initiated the creation of a local instrument constituency around the smart city concept, and this has directly influenced policy capacity at different levels.

\section{Bandung}

A first step in the creation of a smart city constituency in Bandung was through a workshop conducted in September 2013, which paved the way to the subsequent creation of the Smart City Council over the following months. The Smart City Council gathered lecturers from ITB, municipal departments, officers from Telkom Indonesia, and technology entrepreneurs (Labtek Indie, personal communication, April 2nd, 2019). Even though these actors possessed diverse backgrounds, i.e. business, academia or political party, they become members of an instrument constituency through their common practices, interests and visions that centred around the development of smart city in Bandung (Voss \& Simons 2014). The involvement of multiple stakeholders with various backgrounds, training and experiences contributes significantly to the operational capacity of the city. Besides, the Bandung Command Center, which was inaugurated in early 2015, also represents an effort to increase the operational and analytical capacity at the organisational level by encouraging agencies to coordinate better as well as to produce, share and disseminate more evidencebased policies. It was also a strategy, recognised as a "quick win" by local actors to increase visibility and trust from citizens (Bappelitbang Kota Bandung, personal communication, April 1st, 2019), which directly strengthen the political capacity of the government in Bandung. In a 2015 interview, Kamil also pointed out at external socio-demographic factors that also played a role in facilitating the smart city initiative; such as the more than 50 higher education institutions, and the fact that $60 \%$ of the population is under 40 -years old, underpinning the potential of Bandung as an "educational, technological and creative hub" (Oxford Business Group, 2015).

\section{Jakarta}

In Jakarta, Purnama set from the beginning a very strong management style that make it clear to the citizens that his administration will not tolerate any forms of corruption and indolence (Chambers \& Basu, 2016 April 27th). And he indeed fired about half of the officials in his first two months. But he also increased wages to attract the brightest talents and set a specific Smart City Team, which increased both operational and analytical capacities of his administration. Purnama also introduced an application; CROP, to monitor the performance of his officials in responding to citizen complaints. While this was met with opposition within the bureaucracy and the Jakarta Council, it sent clear signals to private companies that business is now easier because of increased transparency and efficiency (Jakarta Smart City, personal communication, May 5th, 2019). The city also purposely encouraged startups to join the smart city initiative, which led to the growing importance of Qlue, an application first designed to answer public complaints more efficiently. Through the Jakarta Disaster 
Mitigation Agency (BPBD), the city collaborated with the University of Wollongong, Australia, and Twitter, to create an application mapping the floods, increasing the city's disaster responsiveness. These various collaborations with non-governmental actors contributed to a greater operational capacity, which also led to the creation of an instrument constituency on the smart city in Jakarta. Similar to Bandung Command Centre, the Jakarta Smart City Lounge was launched in 2015, symbolising the structural promises of a more evidencebased, transparent and less-siloed government.

\begin{tabular}{|c|c|c|}
\hline \multicolumn{2}{|c|}{$\begin{array}{l}\text { Policy capacity at different } \\
\text { levels }\end{array}$} & \multirow{2}{*}{$\begin{array}{l}\text { Examples in Bandung and Jakarta } \\
\text { Training of existing staff and use of external consultants in } \\
\text { Bandung and hiring of highly-skilled employees in Jakarta }\end{array}$} \\
\hline \multirow{3}{*}{$\begin{array}{l}\text { Analytical } \\
\text { capacity }\end{array}$} & Individual & \\
\hline & Organisational & Sharing and use of systematically created data encouraged \\
\hline & Systemic & $\begin{array}{l}\text { High number of universities in both cities, and additionally in } \\
\text { Jakarta high number of international businesses }\end{array}$ \\
\hline \multirow{3}{*}{$\begin{array}{l}\text { Operational } \\
\text { capacity }\end{array}$} & Individual & $\begin{array}{l}\text { New managerial style, increased transparency and } \\
\text { accountability }\end{array}$ \\
\hline & Organisational & Coordination amongst agencies encouraged \\
\hline & Systemic & $\begin{array}{l}\text { Collaboration with associative networks (ex: BCCF) and } \\
\text { universities (ex: ITB) in Bandung, collaboration with startups } \\
\text { (ex: Qlue), multinationals (ex: Google-Waze), universities (ex: } \\
\text { Wollongong) in Jakarta }\end{array}$ \\
\hline \multirow{3}{*}{$\begin{array}{l}\text { Political } \\
\text { capacity }\end{array}$} & Individual & Kamil and Purnama as policy entrepreneur \\
\hline & Organisational & $\begin{array}{l}\text { Newly established dialogue with citizens, mostly through } \\
\text { social media }\end{array}$ \\
\hline & Systemic & $\begin{array}{l}\text { Increased trust in public institutions through transparency and } \\
\text { accountability }\end{array}$ \\
\hline
\end{tabular}

Table 1: The policy capacity in Jakarta and Bandung in smart city development

\subsection{The Impacts of Smart City on Urban Governance}

If Kamil and Purnama have been instrumental in the development of smart city in their respective city, they are no longer in command; Kamil left his position of mayor to become governor of West Java in 2018, while Purnama was defeated in the 2016 election. This invites a first reflection on the sustainability of the changes they made in urban governance. 


\section{Bandung}

It remains difficult to judge if the policy window that Kamil opened for a smart city in Bandung remains viable or not. In his study on the former mayor of London Ken Livingstone and his road congestion pricing policy, Dudley (2013) was able to map the opening of the window and its closing once the project was implemented. For Bandung Smart City, it seems that the window is still open. Kamil's smart city programmes was formalised in Bandung Long Term Development Plan 2014-2018. Some of the action plans are still being implemented to date. A web portal has been launched at the end of 2018 to summarise all the smart city actions happening in Bandung, as well as a City Dashboard to communicate on simple statistics about the different city neighbourhoods. Furthermore, Kamil is now extending this policy window at the regional level as he acceded to the post of governor for the West Java Province in 2018, aiming to transform the region into a Smart Province. But the current mayor of Bandung, Oded Muhammad Danial, who took office in 2018, appears to be less active prioritising smart city development. This was indicated in the limited mention of Smart city in the final draft of Bandung Long Term Development Plan 2018-2023 launched under his leadership. While the preceding document set out the Smart City programme in great detail, the current document, albeit stating a specific goal to improve Bandung's Smart City Maturity ranking (by adopting a set of indicators developed by the local university), did not set out any detailed action plans on how to achieve it, apart from mentioning the need to integrate all existing digital platforms (Bandung RPJMD Final Draft 2018-2023). Similarly, the Smart City Council that was active at the early stage of the smart city, did not turn into a long-term exchange forum by meaningfully engaging various stakeholders who are committed towards smart city development. While some key stakeholders are still working on the smart city domain (i.e. university, associations, government), there is a lack of common vision that could constructively advance the current state of smart city development. However, some of Kamil's legacy that was launched under the guise of smart city has appeared to be enduring. Notably, public agencies continue to report and update their activities on Twitter regularly (Bappelitbang Kota Bandung, personal communication, April 1st, 2019), a newly established dialogue with citizens through social media has been rolled-out, and increased coordination among various agencies to address collective problems has been observed.

Jakarta

In Jakarta, more clearly than in Bandung, the enthusiasm for smart city at the highest leadership level has cooled down since the change in leadership with Anies Baswedan replacing Purnama in 2017. While the city administration still includes a special Smart City task force under the City's Information and Communication Department (the team comprises external and highly skilled non-tenured civil servant.) that is active and fully functioning, the new mayor is reported to be less inclined to promote Jakarta as a smart city, which is often seen as a legacy of his predecessor. Under his leadership, Jakarta joined the 100 Resilient City, which could put the smart city concept secondary to the concept of resilient city. His effort to rebrand Jakarta to cast away the shadow of his predecessors led to some unintended consequences that could potentially undermine the analytical capacity of his administration. For instance, Setiaji, the head of Jakarta Smart City, has decided to leave the city's administration to join Kamil in West Java. However, Sandiaga Uno, who was the vice governor of Baswedan before running for the presidential election, has recognised the 
important steps taken by Purnama earlier in promoting public service efficiency and improving citizens' trust towards the government (Chambers, 2017 May 11th). The new governor is also continuing to push agencies to work together, while the deputy governor of Jakarta for planning, Oswar Muadzin Mungkasa has insisted on the active engagement with the citizens from the bottom-up (Centre for Liveable Cities, 2019). But the rigid rules within the existing bureaucracy remain as a barrier for the development of the city's capacity. For instance, it remains difficult to recruit programmers or data analysts because they often do not meet the rigid criteria to have prior similar job experiences (Jakarta Smart City, personal communication, May 5th, 2019). Even though Jakarta and Bandung are two of the most bustling administrative and commercial hubs in Indonesia and have so far taken the lead in smart city development, to date, a national-level initiative that regulates the legal and governance issues that could arise from smart city development is still lacking. Despite the launch of the urban digitisation programme such as "100 Smart Cities" in 2017, there remains ample room for smart city regulatory frameworks to be firmed out to improve the governance of smart cities in Indonesia.

\section{Discussion - Conclusion}

This paper is a first step to analyse smart city in ASEAN in regards to urban governance. We have identified five policy concepts that appear to be relevant; the MSF, policy entrepreneur, policy mobility, instrument constituency and policy capacity. These could be complemented by a network analysis to identify peripheral actors and policy brokers (Howlett et al., 2017) and to examine their roles as well as their relation to policy entrepreneurs. This initial framework will also be tested on a third city; Makassar which is also a city within the ASEAN Smart City Network but possessing very different contexts from Jakarta and Bandung. For instance, the city does not benefit from the same pool of talents as compared to Jakarta and Bandung, which might hinder its analytical capacity. It seems however, that the former mayor of Makassar; Mohammad Ramdhan Pomanto, did play a policy entrepreneur role, like in Jakarta and Bandung. Kamil and Purnama, through their new management style; a shift from a hierarchical and bureaucratic to a more accessible and engaged leadership (Zaenudin \& Suwatno, 2017), have indeed contributed to the heightening of public's trust towards the government strengthening political capacity at systemic level.

The analysis of smart city in two indonesian cities through the lens of urban governance and public policy study, allows a preliminary conclusion on the functional and structural promises of smart city and more precisely smart planning. From a functional point of view, the smart city development in both Jakarta and Bandung has enhanced administrative management abilities and responsiveness towards city problems such as floods, or slight optimisation of traffic issues. However, it did not materialise in an enhanced ability to conduct long term planning. What it did more successfully is, from a structural point of view, to reshape the city-level governance. Indeed, in both cases, the smart city concept was a window of opportunity to introduce new management styles and promoting transparency; through regular reporting of agencies on social media for instance, accountability; through official performance monitoring app like CROP in Jakarta, or increased cooperation between agencies in sharing data, but also involving external partners; citizens, startup like Qlue or universities like ITB in Bandung, and Wollongong for Jakarta. 
In both cities, the smart city development does not move as fast as it used to be, and this is partly driven by change of leadership, with the new mayor of Bandung and governor of Jakarta less enthusiastic in advancing a policy idea that appears to be more representative of their predecessors (BCCF, personal communication, April 3rd, 2019; Jakarta Smart City, personal communication, May 5th, 2019). In addition, there is also a sentiment within current administration that most of the major steps have been taken, and that the rest has more to do with long term implementation and consolidations of the various initiatives (Jakarta Smart City, personal communication, May 5th, 2019). The recent national initiative of "100 Smart Cities" or the ASEAN Smart City Network that are bringing new momentum for smart city development, could nevertheless give a strong incentive to Jakarta and Bandung to put efforts to maintain their prestigious status as well as to act as examples for lowersized cities. Some like the CEO of Qlue, Rama Raditya, actually consider that the smart city potential has been largely untapped. For him, Jakarta is still far from being smart, since "ideally, a smart city must be built from scratch with cutting-edge technological infrastructure, from undergrounds pipes that are equipped with loT to street lights that have been installed with live sensor technology" (Putera, 2019 April 9th).

Perhaps this is an opportunity to pause and think about the future; does a smart city needs to be more equipped with cutting-edge technology like Raditya has suggested? Or could a smart city espouse a more low-tech approach (Urbanités, 2018), whereby the aim of smart city development is less on techno-solutionism but more on using innovative tools to increase government's responsiveness and efficiency in solving policy problems by actively engaging the citizens and other important stakeholders in the society.

\section{References}

ASEAN (2018). Concept Note, ASEAN Smart City Network.

Bache, I., \& Reardon, L. (2013). An Idea Whose Time has Come? Explaining the Rise of WellBeing in British Politics. Political Studies, 61(4), 898-914. DOI:10.1111/14679248.12001

Béland, D., \& Howlett, M. (2016). How Solutions Chase Problems: Instrument Constituencies in the Policy Process. Governance, 29(3), 393-409. DOI:10.1111/gove.12179

BPS (2018) Statistik Indonesia 2018, Badan Pusat Statistik, Jakarta.

BPS Kota Bandung (2018) Kota Bandung Dalam Angka 2018, Badan Pusat Statistik, Bandung.

Cairney, P. (2018). Three habits of successful policy entrepreneurs. Policy \& Politics, 46(2), 199-215. DOI:10.1332/030557318X15230056771696

Chambers, J. (2017). 'The Interview: Ridwan Kamil, Mayor of Bandung'. Govlnsider, $11^{\text {th }}$ April [online]. Available at: https://govinsider.asia/digital-gov/the-interview-ridwankamil-mayor-of-bandung/ (Accessed: 24 june 2019)

Chambers, J. (2017). 'In the hot seat: Sandiaga Uno, Jakarta's Deputy Governor-elect', GovInsider, $11^{\text {th }}$ May [online]. Available at: https://govinsider.asia/smart-gov/in-thehot-seat-sandiaga-uno-jakartas-deputy-governor-elect/ (Accessed: 24 june 2019) 
Chambers, J., \& Basu, M., (2016) 'Exclusive Interview: Governor of Jakarta', Gov/nsider, 27 $7^{\text {th }}$ April [online]. Available at: https://govinsider.asia/innovation/exclusive-interviewgovernor-of-jakarta/ (Accessed: 24 june 2019)

Centre for Liveable Cities. (2019). 'CLC-Lecture - Juggling Jakarta: Urban Challenges and Solutions'. Available at: https://www.youtube.com/watch?v=DjKXZskzbGU\&feature=youtu.be (Accessed: 24 june 2019)

Cohen, D. (2015). Grounding mobile policies: Ad hoc networks and the creative city in Bandung, Indonesia. Singapore Journal of Tropical Geography, 36(1), 23-37. https://doi.org/10.1111/sjtg.12090

Cox, R. H., \& Béland, D. (2013). Valence, Policy Ideas, and the Rise of Sustainability: Valence and Sustainability. Governance, 26(2), 307-328.

Dudley, G. (2013). Why do ideas succeed and fail over time? The role of narratives in policy windows and the case of the London congestion charge. Journal of European Public Policy, 20(8), 1139-1156. DOI:10.1080/13501763.2013.771090

Firman, T. (2014). Inter-local-government partnership for urban management in decentralizing Indonesia: from below or above? Kartamantul (Greater Yogyakarta) and Jabodetabek (Greater Jakarta) compared. Space and Polity, 18:3, 215-232. DOI: 10.1080/13562576.2014.959252

Howlett, M., Mukherjee, I., \& Koppenjan, J. (2017). Policy learning and policy networks in theory and practice: The role of policy brokers in the Indonesian biodiesel policy network. Policy and Society, 36(2), 233-250. https://doi.org/10.1080/14494035.2017.1321230

Ispranoto, T. (2013). 'Di tangan Kang Emil, Bandung jadi smart city', Sindonews, $14^{\text {th }}$ September [online]. Available at: https://daerah.sindonews.com/read/783004/21/di-tangan-kang-emil-bandung-jadismart-city-1379133217 (Accessed: 24 june 2019)

Kingdon, J. (1984; 1995). Agendas, Alternatives and Public Policies 1st and 2nd eds. New York: Harper Collins.

Kingdon, J. W. (2011). Agendas, Alternatives, and Public Policy. New York Longman.

Kitchin, R. (2015). "Making sense of smart cities: addressing present shortcomings". Cambridge Journal of Regions, Economy and Society, 8(1-1), 131-136 DOI:10.2139/ssrn.2641802

Kitchin, R. (2016). The ethics of smart cities and urban science. Philosophical Transactions. Series A, Mathematical, Physical, and Engineering Sciences, 374(2083). DOI:10.1098/rsta.2016.0115

Kota Bandung (2018) Rancangan Akhir - Rancangan Pembangunan Jangka Menengah Daerah (RPJMD) Kota Bandung 2018-2023, Kota Bandung.

Lovell, H. (2016). The Role of International Policy Transfer Within the Multiple Streams Approach: The Case of Smart Electricity Metering in Australia. Public Administration, 94(3), 754-768. https://doi.org/10.1111/padm.12259 
Mada, R.W. (2015). 'Memahami Ridwan Kamil : Ide, Gagasan dan Tanggapannya Terhadap Kritik', Bixbux, $6^{\text {th }}$ November [online]. Available at: https://bixbux.com/memahamiridwan-kamil-ide-gagasan-dan-tanggapannya-terhadap-kritik/ (Accessed: 24 june 2019)

McLennan, G. (2004). Travelling with vehicular ideas: The case of the third Way. Economy and Society, 33(4), 484-499. DOI:10.1080/0308514042000285251

Meijer, A., \& Rodríguez Bolívar, M. P. (2015). Governing the smart city: a review of the literature on smart urban governance. International Review of Administrative Sciences, 82. DOI:10.1177/0020852314564308

McCann, E. (2011). Urban Policy Mobilities and Global Circuits of Knowledge: Toward a Research Agenda. Annals of the Association of American Geographers, 101(1), 107130. DOI:10.1080/00045608.2010.520219

McCann, E. (2013). Policy Boosterism, Policy Mobilities, and the Extrospective City. Urban Geography, 34(1), 5-29. https://doi.org/10.1080/02723638.2013.778627

Oxford Business Group. (2015). 'Ridwan Kamil, Mayor of Bandung: Interview'. Available at: https://oxfordbusinessgroup.com/interview/obg-talks-ridwan-kamil-mayorbandung (Accessed: 24 june 2019)

Paschoal, B., \& Wegrich, K. (2017). Urban governance innovations in Rio de Janeiro: The political management of digital innovations. Journal of Urban Affairs, 1-18. DOI:10.1080/07352166.2017.1310561

Peck, J. (2011). Geographies of policy: From transfer-diffusion to mobility-mutation. Progress in Human Geography, 35(6), 773-797. https://doi.org/10.5749/minnesota/9780816677306.001.0001

Peck, J. Theodore, N. (2001) Exporting work-fare/importing welfare-to-work: exploring the politics of Third Way policy transfer. Political Geography, 20, 427-460

Peck, J. Theodore, N. (2008). Embedding policy mobilities. Working paper, Department of Geography, University of British Columbia, Vancouver, Canada.

Putera, P.A.W. (2019). 'Interview with Qlue CEO, part II: Smart cities in Indonesia and beyond', Compasslist, $11^{\text {th }}$ April [online]. Available at: https://compasslist.com/insights/Interview-with-Qlue-CEO\%2C-part-II\%3A-Smartcities-in-Indonesia-and-beyond (Accessed: 24 june 2019)

Taeihagh, A. (2017). Crowdsourcing, Sharing Economies and Development. Journal of Developing Societies, 33(2), 191-222. https://doi.org/10.1177/0169796X17710072

Taeihagh, A., \& Lim, H. S. M. (2018). Governing autonomous vehicles: emerging responses for safety, liability, privacy, cybersecurity, and industry risks. Transport Reviews, 126. DOI:10.1080/01441647.2018.1494640

Urbanites (2018). 'Appel \#12 / La ville (s)low tech'. 25th October. Available at : http://www.revue-urbanites.fr/appel-12/ (Accessed: 24 june 2019)

Von Luebke, C. (2009). The political economy of local governance: findings from an Indonesian field study. Bulletin of Indonesian Economic Studies, 45(2), 201-230. 
Voß, J.-P., \& Simons, A. (2014). Instrument constituencies and the supply side of policy innovation: the social life of emissions trading. Environmental Politics, 23(5), 735754. DOI:10.1080/09644016.2014.923625

Wardhani, A.D. (2014). 'Jakarta Launches Smart City Program', The Jakarta Post, $16^{\text {th }}$ December [online]. Available at:

https://www.thejakartapost.com/news/2014/12/16/jakarta-launches-smart-cityprogram.html (Accessed: 24 june 2019)

Wardhani, A.D., Sofian, E.M., \& Elyda, C., (2015). 'Discourse: My way of bureaucratic reform is like playing soccer: Ahok', The Jakarta Post, $19^{\text {th }}$ November [online]. Available at: https://www.thejakartapost.com/news/2015/11/19/discourse-my-waybureaucratic-reform-playing-soccer-ahok.html (Accessed: 24 june 2019)

Wu, X., Ramesh, M., \& Howlett, M. (2015). Policy capacity: A conceptual framework for understanding policy competences and capabilities. Policy and Society, 34(3-4), 165-171. https://doi.org/10.1016/i.polsoc.2015.09.001

Zaenudin, H.N. \& Suwatno, S. (2017). Ridwan Kamil's Digital Public Sphere and Public Policy. IOP Conf. Series: Earth and Environmental Science, 145 (2018) 012007 